Maciej Szpunara)

(D) https://orcid.org/0000-0001-7035-0805

Maciej Zachariasiewicz ${ }^{\text {b) }}$

(Dhttps://orcid.org/0000-0002-2848-0216

Krzysztof Pacuła ${ }^{c}$

(D) https://orcid.org/0000-0002-4492-2360

\title{
Honorary Doctorate for Professor Paul Lagarde and the meeting of the Furopean Group for Private International Law
}

September 2019 blossomed with important events in the private international law at the University of Silesia. The first of these was the annual meeting of the European Group for Private International Law (Groupe européen de droit international privé, abbreviated to EGPIL and GEDIP, respectively in English and French). Established in 1991, GEDIP brings together the most eminent figures of academia and renowned members of international organizations for the purpose of creating, as the Group itself explains, an academic and scientific think tank. The Group focuses mainly on the study of the impact of European integration on private international law.

a) Dr hab., prof. UŚ, University of Silesia, First Advocate General, the Court of Justice of the European Union.

b) Dr hab., prof. ALK, Kozminski University Law School, Warsaw, Poland.

c) Dr, Legal clerk at the Court of Justice of the European Union. 
Each year, at the invitation of one of its members, the Group holds a multi-day meeting devoted to the most current challenges relating to its main point of focus. The proceedings of the working sessions and the statements of the group are posted on its Website (www.gedip-egpil.eu) and published in various law reviews.

These meetings attract not only immense scholar's attention but are also closely followed by the practitioners. The outcomes of the Group's workings often serve as an impulse for legislative action both at national and supranational levels. Suffice is to note that the recommendations and draft legislation of the Group has been referred to in the legislative process of the European Union.

From 13 to 15 September 2019, the Faculty of Law and Administration of the University of Silesia had the honour of hosting the 29th meeting of the Group, which had been organized at the invitation of one its members, M. Szpunar.

The meeting in Katowice was attended by the following members of the Group: C. Kessedjian, President of the Group, P. Kinsch, Secretary General, S. Bariatti, J. Basedow, M. Bogdan, A. Bonomi, G. Cordero-Moss, M. Fallon, F. J. Garcimartín Alférez, A. Giardina, C. González Beilfuss, T. Hartley, F. Jault-Seseke, Ch. Kohler, P. Lagarde, J. Meeusen, G. Möller, P.A. Nielsen, E. Pataut, M. Pauknerová, F. Pocar, M. Szpunar, H. van Loon and M.-Ph. Weller.

In addition, the Group invited A. Stein and M. Wilderspin from the European Commission, as well the representatives of the organizers, M. Pazdan, W. Popiołek, M. Jagielska and K. Pacuła, to participate in the meeting.

The meeting was also assisted by J. Mary and M. Dechamps.

In the course of the 29th meeting, the members of the Group delved into a number of issues that had been unmistakably identified as the most persisting challenges that the private international law has to address in the future.

Against this background, the Group presented and discussed the draft project on the law applicable to rights in rem. It then went on to discuss a possible European regulation on the private international law of divorce, which largely amends the Brussels IIa Regulation.

Next, the Group's focus moved towards the discussion on a proposal for the codification of the general part of European Private International Law. This discussion had been preceded by the remarks on the interplay between the general part of private international law and the primary law of the EU, presented by Ch. Kohler. 
The next point of the agenda was the presentation of the report on the case law of the European Court of Human Rights and its implications for the private international law, delivered by P. Kinsch.

Subsequently, the members of the Group reflected on the newly adopted Convention on the Recognition and Enforcement of Foreign Judgments in Civil or Commercial Matters (HCCH 2019 Judgments Convention).

The Group then delved into the issue of corporate liability for violations of human rights and environmental damage.

During the meeting, the Group adopted the „Proposal of a Regulation on jurisdiction, applicable law and recognition of judgments and decrees with regard to divorce and legal separation". The Proposal seeks to bring within a single instrument, for the first time, all the rules pertaining to jurisdiction, applicable law and recognition in matters of divorce. It also refines the rules provided for in the EU private international law, i.e. in the Brussels IIa Regulation and its successor, the Recast Regulation 2019/1111.

Moreover, in reaction to the regrettable decrease in the number of Members States of the International Commission on Civil Status (ICCS), the Group adopted its recommendation concerning the need to maintain and develop international cooperation in matters of civil status.

Due to the circumstances linked to COVID-19 the annual meeting of 2020 was held online. The next meeting of the Group will take place in Prague, in 2021.

The other memorable event of September 2019 at the University of Silesia was the ceremony of awarding the honorary „doctorate” (honoris causa) to one of the leading scholars of the 20th century in private international law - Professor Paul Lagarde. This is the highest academic distinction, which academia can bestow on someone. Since its inception, the University of Silesia has granted this distinction only to 59 people. The event took place on 13th September 2019. The request of the Council of the Faculty of Law and Administration in this matter was approved by the University Senate on 25th June 2019 (Resolution No. 396).

Professor Paul Lagarde is one of the most outstanding contemporary lawyers dealing with private international law. An author of numerous publications in this field, he has been, for the last 60 years, a source of inspiration for scholars around the world. His impactful contributions has been profoundly studied, discussed and cited also in Poland, and in particular in Katowice, which has been the centre for private international scholarship in Poland since the 1970s. Professor Lagarde's works ravished with precision and clarity of the argument. He addressed almost all of the major issues of the private international law, starting with 
the public policy exception, which he covered in what has become a classic work in the field: Recherches sur l'ordre public en droit international privé (Paris 1959). He has also elucidated the central role of the principle of proximity in the private international law in his famous Le principe de proximité dans le droit international privé contemporain. Cours général de droit international privé (Recueil des cours de l'Académie de Droit international de la Haye, vol. 196, 1986-I). More recently, Professor Lagarde directed the work on one of the most controversial, yet relevant topics in modern conflict of laws: the recognition of "situations" ( $L a$ reconnaissance des situations en droit international privé, Paris 2013).

Professor Paul Lagarde was a member of numerous academic associations including the GEDIP since its foundation in 1991, the Comite français de droit international privé, where he served as a president, and the Institut de Droit International, of which he is a member since 1995. Between 1976-2012 he was the rédacteur en chef and afterwards the director of the Revue critique de droit international privé, the main French journal dealing with private international law. Professor Lagarde has also led or participated in numerous intergovernmental bodies and expert groups that have made a significant contribution to the development of instruments related to private international law. He took part in preparatory works for what became the ground-breaking Rome Convention on the law applicable to contractual obligations (1980). He served as a secretary general of the Commission Internationale de l'État Civil (2000-2009) as well as an expert in the European Commission's group, which laid groundwork for the European Union's private international law relating to successions and matrimonial and partnership property regimes. There are no doubts that Professor Lagarde had a farreaching impact not just on the private international law as an academic discipline but, more generally, also on the international cooperation in the European Union and worldwide.

The contemporary European history recognizes Professor Lagarde as a devoted scholar and teacher to many generations of lawyers, an influential expert, and an internationalist whose works have contributed to common legal culture in Europe. In Katowice, he is remembered as a forthcoming supporter for many Polish scholars coming to Paris, and, last but not least, as a kind friend. 